\title{
Self Efficacy as Predictor of Organizational Commitment among Revenue Personnel
}

\author{
Sonal Agarwal ${ }^{1 *}$, P.C Mishra ${ }^{2}$
}

\section{ABSTRACT}

Organizational commitment is becoming increasingly recognized in industrial/organizational literature. Self efficacy beliefs affect performance in a wide spectrum of life including the work place. The aim of the present study was to explore the relationship between self efficacy and organizational commitment and to find out the extent to which self efficacy significantly predicts organizational commitment among revenue personnel. It was hypothesized that the relationship between self efficacy and organizational commitment will be positive and that self efficacy will significantly predict organizational commitment. For this purpose, a sample of one hundred revenue personnel, in the age range of thirty to forty years were incidentally selected from Lucknow and other nearby cities and districts of India. The minimum job experience of the participants was five years. Self efficacy was measured using the Generalized self efficacy scale by Schwarzer and Jerusalem (1995).The organizational commitment scale developed by Khan and Mishra [2002], was used to measure the commitment of employees towards their organization. Pearson product moment correlation analysis and regression analysis was conducted on the obtained data. Results reveal a positive and significant relationship between self efficacy and organizational commitment[ $r=0.356]$ [ $p$ value 0.01]. A positive significant relationship was also found between self efficacy and the three sub scales of organizational commitment namely affective commitment, continuance commitment and normative commitment. Further, the regression analysis revealed that self efficacy significantly predicts organizational commitment among revenue personnel.

Keywords: Self- efficacy, Organizational commitment.

Organizational commitment is becoming increasingly recognized in organizational literature. With the advent of industrialization, privatization and globalization, an increasing sense of job insecurity and work related stress have risen. With the rise in job opportunities, organizational

\footnotetext{
${ }^{1}$ Senior Research fellow [UGC], Department of Psychology, University of Lucknow, Lucknow, India

${ }^{2}$ Professor, Department of Psychology, University of Lucknow, Lucknow, India

*Responding Author

(C) 2016, S Agarwal, P Mishra; licensee IJIP. This is an Open Access Research distributed under the terms of the Creative Commons Attribution License (http://creativecommons.org/licenses/by/2.0), which permits unrestricted use, distribution, and reproduction in any Medium, provided the original work is properly cited.
} 


\section{Self Efficacy as Predictor of Organizational Commitment among Revenue Personnel}

commitment has emerged as a great challenge in modern times. Mowday et al.(1982) viewed organizational commitment as relative strength of an individual's identification with and involvement in an organization. Williams and Hazer [1986] considered organizational commitment to be an attitude with three components as follows;

1-Belief in the organizational goals and values

2- Willingness to extend effort on behalf of the organization and

3- Desire to remain in the organization [Morrow 1983]. They assumed that commitment represents a global attitude about the organization as a whole.

Meyer, Allen and Gellatly [1991] have identified three basis of organizational commitment. These are;

1. Affective commitment -This refers to the employee's emotional attachment, identification and involvement with the organization.

2. Continuance commitment- This refers to the employee's motive to continue with the organization because leaving may be costlier and he/she may not be able to afford to it.

3. Normative commitment -This refers to employee's moral obligation to remain with the organization.

Numerous researches have been done which support the three component model of organizational commitment.

Pertinent literature suggests that a large number of factors influence an employee's commitment towards his organization including age, tenure, education, marital status and gender. [ Ritzer and Trice (1969), Alutto and others (1973), Porter and other (1974),Steers (1977), Angle and Perry (1981), Cohen (1992)].

Further, Luthans and Youssef (2007) found that organizational commitment is positively related to hope, resilience and optimism.

The present study attempts to investigate the relationship between the positive construct of self efficacy and organizational commitment.

Bandura (1997) defined self-efficacy as “people’s beliefs in their capabilities to produce desired effects by their own actions. Similarly Maddux (2002, p 278) has described self - efficacy as “what I believed, I can do with my skill under certain conditions". Bandura [1989a, 1989b, 1977, 1997] proposed that the developmental antecedents of self efficacy include previous successes in similar situations, modeling on others in the same situations. Imagining oneself behaving effectively, undergoing verbal persuasion by powerful trustworthy experts and arousal and emotions. 


\section{Self Efficacy as Predictor of Organizational Commitment among Revenue Personnel}

Self efficacy has been implicated in successful coping with a variety of psychological problems [Maddux 1995]

Researches reveal that higher a person's belief in his / her ability to perform the desired action, the greater the successes in various fields of life including academic accomplishments, improvement in health and better performances at work.

In work place, employees who possess a high level of self efficacy are more likely to exert greater efforts even in difficult situations and thereby produce more favorable outcomes. Since highly committed employees significantly perform better in their organizations, it is necessary to study various factors which predict organizational commitment. In this study, attempt has been made to find out the relationship between self efficacy and organizational commitment and the extent to which people's belief in their ability to produce the desired effect by their own action predicts their organizational commitment.

In a study done by Arya et al [2012], it was found that a positive relation exists between self efficacy and organizational commitment. Further the regression analysis indicated gender role orientation along with self efficacy is the strongest predictor of organizational commitment among employees. Sinha et al [2002] studied 167 members of Tata Engineering and Locomotive Company of India and explored the relationship between self efficacy and organizational commitment. Results revealed that organizational commitment is positively related with self efficacy. Although numerous researches have been done to find out the relationship between self efficacy belief and organizational commitment, extremely few study have been done investigating these two psychological constructs in the revenue department of India. The Income Tax department of India is an extremely important department which has an unparallel contribution in the efficient and effective functioning of the economy. Hence, this study is done on revenue personnel's working in Lucknow and other nearby cities and districts [India].

\section{Purpose}

1. The aim of the study is to find out how self efficacy is related to organizational commitment among revenue personnel.

2. The study also attempts to find out the extent to which self efficacy predicts organizational commitment among revenue personnel.

\section{Hypothesis}

1. In the direction of the available literature concerning the relationship of self efficacy and organizational commitment, the following hypothesis was formulated. Self efficacy will be positively related to organizational commitment among revenue personnel.

2. It was also hypothesized that self efficacy will be a significant predictor of organizational commitment among revenue personnel. 


\section{Self Efficacy as Predictor of Organizational Commitment among Revenue Personnel}

\section{Nature Of Study}

The present study was co relational in nature. In a co relational research design, we observe and measure the relationship between variables which occur naturally without our assistance The present investigation was primarily focusing on two variables namely organizational commitment and self efficacy where organizational commitment was the criterion variable and self efficacy was the predictor variable.

\section{Sample}

The study was conducted on one hundred income tax personnel, incidentally selected from Lucknow and other nearby cities and districts. The age of the respondents ranged between thirty to forty years. All the respondents were married males and well versed in English language. The minimum job experience of the participants was five years [mean=11 years]. The minimum educational qualification of the participants was graduation. The participants included Tax assistants, Income tax inspectors, Income tax officers and Assistant commissioners. All the participants in the study were those who were recruited to work in the revenue department by the Staff Selection Commission of India.

\section{Measures}

The following psychometric tests were utilized for studying the two variables.

- Organizational commitment scale by Khan and Mishra (2002) was used to measure organizational commitment. The scale consists of eighteen items with five alternative responses. The three sub- scales of it are affective commitment, continuance commitment and normative commitment. The scale is reliable and valid.

- The level of Self efficacy was assessed with the help of Generalized Self Efficacy scale by Schwarzer and Jerusalem (1995).The scale consists of ten items with four alternative responses. Internal reliability for G.S.E equals Cronbachs alpha between 0.76 and 0.90 .The general self efficacy scale is correlated to optimism and work satisfaction. Negative coefficients were found for depression, stress, health complaints and anxiety. .

\section{Procedure}

In order to collect the data, the officers working in income tax departments, in and around the city of Lucknow and other nearby cities and districts were contacted individually in their offices. They were briefed about the objectives of the study and were assured that their responses will be held confidential.

The demographic sheet and the required psychometric scales were given to them. After the data was collected, the officers were thanked for their cooperation.

\section{Method Of Data Analysis}

Coefficient of correlation was computed for the relationship between self efficacy and organizational commitment [overall and area wise]. 
A simple linear regression analysis was also conducted to find out the extent to which self efficacy predicts organizational commitment among revenue personnel.

\section{RESULTS}

TABLE 1: Correlation Coefficients of Self-efficacy with organizational commitment

\begin{tabular}{|l|l|}
\hline Variable & Self efficacy \\
\hline Organizational commitment & $0.356^{* *}$ \\
\hline Affective commitment & $0.37^{* *}$ \\
\hline Continuance commitment & $0.34^{* *}$ \\
\hline Normative commitment & $0.32^{* *}$ \\
\hline
\end{tabular}

Note-A positive and significant relationship is found between self efficacy and organizational commitment [overall and area wise].

\section{TABLE 2: The Regression model}

Criterion -Organizational commitment

\begin{tabular}{|l|l|l|l|l|l|}
\hline Predictor & Beta & R & R Sq & F value & P \\
\hline $\begin{array}{l}\text { Self } \\
\text { efficacy }\end{array}$ & .685 & .356 & .127 & 14.255 & $.000^{\mathrm{b}}$ \\
\hline
\end{tabular}

Note- The predictive value of self efficacy in relation to organizational commitment was assessed through simple linear regression analysis. Results indicate that overall the regression model was significant and explained about 12.7 present variance in organizational commitment. ( $\mathrm{R} \mathrm{Sq}=0.127, \mathrm{~F}=14.255, \mathrm{p}=.000^{\mathrm{b}}$ ). Self -efficacy is a significant predictor of organizational commitment (beta=0.685,t= $3.776, \mathrm{p}=0.000)$.

\section{DISCUSSION}

Organizational commitment has increasingly grown in popularity in industrial/organizational literature. It involves more than passive loyalty to an organization, instead it involves an active participation where the individuals are willing to exert their efforts in order to help the organization succeed.

The aim of the present study was to explore the relationship between organizational commitment and self efficacy among revenue personnel. The study also attempted to find out the extent to which self efficacy significantly predicts commitment of individuals towards their organization. Based on previous research, it was hypothesized that the relationship between the two variables namely organizational commitment and self efficacy will be positive and that self efficacy will predict organizational commitment. For this purpose a sample of one hundred income tax personnel in the age range of thirty to forty years were incidentally selected from Lucknow and other nearby cities and districts. Organizational commitment was quantified by using the Organizational commitment scale developed by Khan and Mishra [2002]. The level of self efficacy was assessed with the help of the Generalized Self Efficacy scale developed by

(C) The International Journal of Indian Psychology, ISSN 2348-5396 (e)| ISSN: 2349-3429 (p) | 48 


\section{Self Efficacy as Predictor of Organizational Commitment among Revenue Personnel}

Schwarzer and jerusalem1995. Pearson product moment correlation analysis was done to find out the relationship between self efficacy and organizational commitment, overall and area wise. Simple regression analysis was also conducted.

Results reveal a statistically significant positive relationship between the overall score of organizational commitment and self efficacy [ $r=0.356][\mathrm{p}$ value $=0.01]$. While analyzing the sub scales of organizational commitment, it was found that the correlation between self efficacy and affective commitment was $\mathrm{r}=0.37$, which was also statistically significant. The coefficient of correlation between self efficacy and continuance commitment sub scale was found to be positive and significant $[\mathrm{r}=0.34]$

Continuance commitment is generally believed to develop on the basis of an economic rational [Stevens and his associates, 1978] Further, there was a modest positive correlation between self efficacy and the normative commitment sub scale [ $\mathrm{r}=0.32]$.

\section{Thus hypothesis 1 is accepted.}

The results of regression analysis reveal that the coefficient of determination of goodness of model [ $\mathrm{R}$ square is 0.127]. This implies that $12.7 \%$ of the variability in organizational commitment can be explained by the level of self efficacy. Analysis of variance reveals that the regression model is significant [ $\mathrm{f}$ value $=14.25$ ] [ $\mathrm{p}$ value $=0.000$ ]. The t test analysis further indicates that self efficacy significantly predicts organizational commitment $[t=3.776][p=0.000]$

\section{Thus, hypothesis 2 is accepted.}

The results of this study are also supported by a study done by Bogler and Somech , (2004) which found that self efficacy is a significant predictor of organizational professional commitment .

\section{CONCLUSION}

Self efficacy is a construct which is prospective in nature and pertains to the projections of future performances .It is a positive contributor to a wide range of performances including the work place.

The current study aimed to explore the relationship between self efficacy and organizational commitment and to find out whether self efficacy significantly predicts organizational commitment among revenue personnel. Results reveal a positive and statistically significant relationship between self efficacy and organizational commitment [ $\mathrm{r}=0.356$ ][ $\mathrm{p}$ value $=0.01]$.It was also found that the correlation between self efficacy and the three sub- scales of organizational commitment namely affective commitment, continuance commitment and normative commitment was positive and significant. 


\section{Self Efficacy as Predictor of Organizational Commitment among Revenue Personnel}

The current study further indicated that self efficacy is a significant predictor of organizational commitment among revenue personnel.

Since both self efficacy and organizational commitment have gained in popularity in organizational literature over the past decade owing to the impact they have on job performance, efforts can be made to enhance the level of self efficacy to improve task performance. According to social cognitive theory, self efficacy is a learned pattern of thinking and researches indicate that it can be enhanced significantly with appropriate interventions.

Mathiew et al.[1990] indicate that a positive relationship exists between organizational commitment and desirable outcomes like high job performance and low absenteeism. Thus, efforts made to improve an employee's level of self efficacy and feeling of commitment will particularly be useful for any organization as a whole.

\section{Limitations and Suggestions}

The current study was co relational in nature and thus could not establish any cause and effect relationship between the two variables under study namely self efficacy and organizational commitment. Future researches in this area can use an experimental design to explore the causal relationship between the variables.

Further, generalizations based on the current research findings would be difficult to make as the study was done on a limited sample of one hundred government officials working in the revenue department, who were incidentally selected from the city of Lucknow and nearby districts. Future researches can take a broader and a more representative sample from across many cities/states.

\section{Acknowledgments}

The author appreciates all those who participated in the study and helped to facilitate the research process.

\section{Conflict of Interests}

The author declared no conflict of interests.

\section{REFERENCES}

Arya, B., Sharma ,M., \& Singh, S. [2012]. Moderating effect of gender role orientation on the relationship between organizational commitment and self efficacy. International Journal of Scientific and Research Publication, 2: 1-5

Angle, H.L. and Perny, J.L. [1981]. An Empirical Assessment of Organizational Commitment and Organizational Effectiveness. Administrative Science Quarterly, Vol. 26(1), 1-14. 


\section{Self Efficacy as Predictor of Organizational Commitment among Revenue Personnel}

Bandura, A.(1977).Self efficacy: Towards a unifying theory of behavior change. Psychological Review , 84,191-215.

Bandura ,A.[1989a]. Human agency in social cognitive theory. American Psychologist, 44, 1175- 1184.

Bandura, A. [1989b] .Regulation of cognitive processes through perceived self efficacy. Developmental Psychology, 25,729-735.

Bandura ,A. [1997]. Self efficacy: The exercise of control. New York: Freeman.

Bogler , R., \& Somech, A. [ 2004] . Influence of teacher empowerment on teachers organizational commitment, professional commitment and organizational citizenship behavior in schools. Journal of teaching and teacher education, 20, 277-289.

Cohen. A, [1992]. Antecedents of Organizational Commitment across Occupational Groups: A Meta-Analysis. Journal of Organizational Behavior, Vol.13, , PP 539-558.

Luthans.F., and Youssef, C.M.[2007] Emerging positive organizational behavior. Journal of Management, 33,321-349.

Maddux, J.E.(Ed).(1995). Self efficacy, adaptation, and adjustment: Theory, research, and application. New York: Plenum.

Maddux, J.E.(2002). Self efficacy: The power of believing you can. In C.R. Snyder \& S.J. Lopez (Eds.), The handbook of positive psychology (pp.277-287).New York: Oxford University Press.

Mathiew, J.E. and Zajac, D.M[1990] ., "A Review and Meta-Analysis of the Antecedents, Correlates, and Consequences of Organizational Commitment”, Psychological Bulletin, Vol. 108, , PP 171-199.

Meyer, J.P., Allen, N.J., \& Gallatly [1991] . A Three-component Conceptualization of Organizational Commitment. Human Resource Management Review, Vol.1, Pg 61-89.

Mowday, R.T.; Porter , L.W. and Steers ,R.M.(1982).Employees Organization Linkages. Academic Press. New York.

Morrow, (1983). Concept redundancy in organizational research. The case of work commitment. Academy of Management Journal, 8, 486-500.

Porter, L.W., Steers, R.M. Mowday, R.T. and Boulian, P.V.[1974] . Organizational Commitment, Job Satisfaction and Turnover among Psychiatric Technicians. Journal of Applied Psychology, Vol.59(5) PP.603-609.

Ritzer,G and Trice,H.M.(1969)An empirical study of Howard Beckers sidebet theory, Social Forces47,475-479

Schwarzer, r \& Jerusalem m (1995). Generalized Self Efficacy Scale.In J Weinman,S Wright \& $\mathrm{m}$ Johnston, Measures in health psychology; A users portfolio. Casual and control beliefs ( pp 35-37]

Sinha, P S,Talwar, T, and Rajpal ,R 2002. Co relational study of organizational commitment , self efficacy and psychological barriers to technological change. Psycho logia ,45[3], 176-183 


\section{Self Efficacy as Predictor of Organizational Commitment among Revenue Personnel}

Snyder, C R and Lopez,S J. Positive Psychology ,the scientific and practical exploration of human strengths. SAGE publications.

Steers, R.M. [1997] . Antecedents and Outcomes of Organizational Commitment. Administrative Science Quarterly, Vol. 22(1), PP 46-56.

Steven, J.M., Beyer, J.M. and Trice, H.M., 'Assessing Personal Role and Organizational Predictors of Managerial Commitment'. Academy of Management Journal, Vol.21, 1978, PP 380-396.

Williams, L.J. and Hazer, J.T.(1986). Antecedents and consequences of satisfaction commitment in turnover models: A reanalysis using latest variable structural equation Methods. Journal of Applied Psychology, 71, 219-231.

How to cite this article: S Agarwal, P Mishra (2016), Self Efficacy as Predictor of Organizational Commitment among Revenue Personnel, International Journal of Indian Psychology, Volume 3, Issue 4, No. 67, ISSN:2348-5396 (e), ISSN:2349-3429 (p), DIP:18.01.179/20160304, ISBN:978-1-365-39397-6 